\title{
Grazing Management Practices Affect Lifestock Losses from Poisonous Plants
}

\author{
LEO B. MERRILL AND JOSEPH L. SCHUSTER
}

HIGHLIGHT: Moderate stocking with cattle, sheep, and goats in a 4-pasture deferred-rotation system or light continuous stocking with cattle, sheep, and goats prevented livestock poisoning by bitterweed (Hymenoxys odorata), shinoak (Quercus mohriana), liveoak ( $Q$. virginiana), and sacahuista (Nolina texana) over a 20year period. Heavy stocking rates generally increased the incidence of poisoning. Using combinations of livestock reduced incidence of bitterweed and sacahuista poisoning, but not oak poisoning. The findings are attributed to better range conditions and forage variety under continuous light stocking and moderate stocking with a 4-pasture deferred-rotation system than under continuous stocking at moderate and heavy rates.

\section{Grazing Management Practices Affect}

\section{Livestock Losses from Poisonous Plants}

There appears little doubt that grazing abuse on rangelands is the most significant cause of death losses from poisonous plants. Stoddart and Smith (1943) stated that poisonous plants with few exceptions are not climax species, but invading species or those that increase with heavy grazing use. Generally, animals do not graze them by choice and are rarely poisoned when they have an abundance of good forage. Stoddart and Smith further stated that most losses from poisonous plants are caused when animals are hungry due to poor forage conditions brought about by ovcr-grazing. Cory (1949) pointed out that the cause of death losses in sheep from bitterweed (Hymenoxys odorata) in Texas in 1923 and 1924 was because bitterweed was steadily becoming more abundant as ranges were more heavily grazed. Certain poisonous species of the Compositae family including bitterweed, rubberweed (Hymenoxys richardsonii var. floribunda), and broomweed (Gutierrezia microcephala) a re eaten only when animals are hungry or searching for green feed in early spring. Increase in population density of these plants is generally considered indicative of overgrazing (James and Johnson 1976) and poor range conditions.

Some poisonous species are normal constituents of the climax community and can cause poisoning under any range condition. Locoweed (Astragalus spp.), for example, is a plant which might cause poisoning even on ranges in good condition. Horses are particularly susceptible, but cattle, sheep and goats may develop loco poisoning (Sperry et al. 1963). Animals at first consume locoweed when it is green and other plants are dry. Once the animals begin eating it,

Authors are professor in charge. Sonora Experiment Station. Sonora. Texas 76950 and professor and head, Range Science Department. Texas A\&M University. College Station, 77843

Manuscript received March 30, 1978 they become addicted and will seek out locoweed - even dried and blackened year-old stems (James et al. 1968).

The presence of a poisonous species in a plant complex will generally not cause livestock poisoning until its relative palatability or some other factor causes it to be consumed by the animals. Poisonous plants can be classified into three categories according to their palatability and toxicity relationship: (1) those that are relatively palatable and comprise an important portion of forage consumed, but cause poisoning only during certain growth periods or forage conditions; (2) those that are relatively palatable and poisonous at all times; and (3) those that are relatively unpalatable and poisonous at all times. Grazing systems developed to prevent poisoning by species in any of these categories must consider both their relative palatability and their toxic stage.

Examples of the first category are the oaks (Quercus spp.). Two species of the Edwards Plateau region of Texas having relatively high palatability and forage value are liveoak (Quercus virginiana) and shinoak (Q. mohriana). In the spring, however, especially when the plants are budding and make up a major portion of the diet of livestock, these species are quite toxic. They frequently cause rather severe death losses (Dollahite et al. 1966). The buds, young leaves, flowers and acorns of oaks can be poisonous to cattle, sheep, and goats (Sperry et al. 1963).

Larkspurs (Delphinium spp.) are examples of poisonous species which are generally always palatable even in the presence of desirable forage plants. James and Johnson (1976) stated that larkspurs are readily grazed by cattle, thus making prevention of poisoning more difficult than with most plants. Poisoning from this type plant is most difficult to control since a nimals consume it even when it makes up a minute portion of the plant complex. Vegetation management may greatly reduce its presence, but the threat of animal losses is always present.

Bitterweed is an example of species which are both unpalatable and poisonous. Since it is unpalatable, bitterweed is consumed primarily when starvation causes consumption or by accident. Hardy et al. (1931) found that it was impossible to induce sheep to eat bitterweed when they were confined with the plant in small exclosures or when the plant was offered free choice in a barn. They concluded, therefore, that primary consumption of bitterweed was accidental while in the act of eating palatable plants. This is generally true, but there is considerable undocumented evidence that sheep will feed on bitterweed when hungry and bitterweed is young and the only green forage available. 
Bitterweed is a cool-season annual that does not compete successfully with perennial plants under proper grazing management. Its density can thus be reduced by grazing systems which enhance range condition (Sperry 1949).

Thus we see that poisonous plants vary widely in palatability and toxicity. They also vary in ability to compete with other range plants. Some species such as bitterweed are annuals found in early seral stages of succession, while others such as larkspurs are abundant in climax. Despite wide differences they may all be manipulated to some extent by grazing management to reduce or eliminate death losses.

\section{Grazing Management and Its Affect on Livestock Losses}

We have attempted to place poisonous plants into three general categories based on their inherent toxicity and palatability. The species considered in the studies reported here fall into these general categories. These plants are sacahuista (Nolina texana), a climax plant which causes problems under good range conditions; liveoak and shinoak, which cause problems under a wide range of range condition; and bitterweed, which is generally a problem only under poor range conditions.

Studies of various grazing management practices were started on the Texas A\&M University Sonora Research Station in 1949. One of the primary goals of these studies was to determine if grazing management would have an influence on losses from poisonous plants. Three rates of stocking, a deferred-rotation grazing system, and combinations of different kinds of livestock were studied from 1949 to 1970 . The three rates of stocking studies were: heavy -48 animal units per section (au/sec); moderate $-32 \mathrm{au} / \mathrm{sec}$; and light $-16 \mathrm{au} / \mathrm{sec}$. Continuous year-long grazing was compared with a 4-pasture deferred rotation system. In this system each pasture is deferred 4 months then grazed 12 months. One pasture is deferred while the remaining 3 pastures are grazed. The combinations of animals grazed were: cattle alone; sheep alone; goats alone; cattle and goats in combination ( $1 / 2$ au cattle, $1 / 2$ au goats); and cattle, sheep, and goats in combination ( $1 / 2$ au cattle, $1 / 4$ au sheep, and $1 / 4$ au goats).

Death losscs from poisonous plants were most severe at heavy rates of stocking, while losses were seldom encountered at the light rates. Death losses were also directly related to kinds or combinations of livestock being grazed. In every instance of livestock poisoning, the cause could be related to a low level of nutrition at the time of the loss. We conclude, therefore, that in this area of the Edwards Plateau of Texas, livestock losses from poisonous plants occur only as a result of poor forage conditions which force the animals to eat excessive amounts of poisonous plants. Death losses were also always more severe when a single kind of livestock was being grazed at the heavy stocking rate than when a combination of livestock made up the stocking rate.

\section{Bitterweed Poisoning}

Bitterweed is an invader plant on most range sites of the Edwards Plateau of Texas. It grows primarily in bare areas, especially bare areas, which have been recently disturbed. It is poisonous to all kinds of livestock, but is primarily a problem in sheep. Bitterweed poisoning occurred only in sheep during the study period. Sheep poisoning was related to the rate of stocking, kinds or combinations of livestock, and to the grazing system. Under continuous grazing the
Table 1. Average yearly death losses $(\%)$ of sheep from bitterweed under continuous grazing at three rates of stocking and two combinations of livestock on the Sonora Experiment Station, 1949-70.

\begin{tabular}{lcccc}
\hline \multirow{2}{*}{ Kind of livestock ${ }^{2}$} & \multicolumn{4}{c}{ Stocking ratel } \\
\cline { 2 - 5 } & Heavy & Moderate & Light & Avg. \\
\hline Sheep only & 8.5 & 4.8 & 1.3 & 4.9 \\
Cattle, sheep and goats & 4.0 & 1.7 & 0.0 & 1.9 \\
Avg. & 6.3 & 3.3 & 0.7 & \\
\hline
\end{tabular}

'Stocking rate: Heavy $=48 \mathrm{au} / \mathrm{sec} ;$ Moderate $=32 \mathrm{au} / \mathrm{sec} ;$ Light $=16 \mathrm{au} / \mathrm{sec}$.

${ }^{2}$ Combination in animal units was $1 / 2$ cattle; $1 / 4$ sheep; and $1 / 4$ goats.

average yearly death losses were greatest at heavy rates of stocking $(6.3 \%)$, second at the moderate rate $(3.3 \%)$, and lowest at light rates of stocking $(.7 \%)$ (Table 1$)$. The stocking rates brought about different range and forage conditions. The heavy stocking rate created fair to poor range conditions while the moderate and light rates of stocking created fair to good range conditions. Bitterweed was more prevalent and less forage was available in heavily stocked pastures, so sheep were forced to eat it because of hunger.

Sheep death losses due to bitterweed poisoning were encountered in 12 years of the 20 years of the study on continuously grazed pastures heavily stocked with sheep only. They were encountered in 8 years under moderate stocking with sheep only, but in only 3 years under heavy grazing cattle, sheep, and goats. Thus, using a combination of livestock reduced the incidence of death losses due to bitterweed.

There were no death losses due to bitterweed poisoning over the 20 year period in the moderately stocked 4-pasture deferred-rotation system grazed with cattle, sheep and goats. Regardless of the stocking rate, death losses were greatest on pastures stocked with sheep only and least when stocking was with a combination cattle, sheep, and goats (Tablc 1). Similar systems and stocking reduced losses, but have not completely eliminated death losses from bitterweed at the Barnhart Research Station $100 \mathrm{~km}$ northwest of the Sonora Station.

\section{Sacahuista Poisoning}

Sacahuista is a climax species of the Edwards Plateau and Trans Pecos regions of Texas. It also occurs in Arizona, New Mexico, Texas and northern Mexico. Its flowers and fruits are toxic to cattle, sheep, and goats, but its green foliage is often valued as good forage during dry periods (Sperry et al. 1963).

Death losses from this plant were very positively influenced by grazing management. No cattle or sheep were lost to sacahuista poisoning on the Sonora Station during the period of the study when range conditions were low-fair or better, but death losses did occur on surrounding ranches. This is attributed to heavier stocking and lower range conditions on the surrounding ranches than on the heavily stocked pastures used in these studies.

Sacahuista poisoning did occur in goats, however. Under continuous grazing average yearly death losses were $4.0 \%$ at heavy rates of stocking, $3.3 \%$ at moderate rates, and $1.7 \%$ at light rates (Table 2). Average yearly goat death losses from sacahuista were greatest (5\%) when goats were grazed alone; second highest $(2.5 \%)$ when cattle and goats were grazed in combination; and least $(1.5 \%)$ when cattle, sheep, and goats were grazed together. This reflects decreasing numbers of goats per pasture, but also reflects less total grazing pressure 
Table 2. Average yearly death losses (\%) of goats from sacahuista poisoning under continuous grazing at three rates of stocking and with three combinations of livestock on the Sonora Experiment Station, 1949-70.

\begin{tabular}{lcccc}
\hline \hline \multirow{2}{*}{ Kind of livestock } & \multicolumn{4}{c}{ Rate of stocking1 } \\
\cline { 2 - 5 } & Heavy & Moderate & Light & Avg. \\
\hline Goats only & 8.6 & 3.8 & 2.5 & 5.0 \\
Cattle and goats & 2.2 & 2.9 & 2.5 & 2.5 \\
Cattle, sheep, and goats & 1.1 & 3.3 & 0.0 & 1.5 \\
Avg. \% loss & 4.0 & 3.3 & 1.7 & \\
\hline
\end{tabular}

Stocking rate: Heavy $=48 \mathrm{au} / \mathrm{sec} ;$ Moderate $=32 \mathrm{au} / \mathrm{sec} ;$ Light $=16 \mathrm{au} / \mathrm{scc}$.

2 Combination in animal units with cattle, sheep and goats was $1 / 2$ cattle, $1 / 4$ sheep, and $1 / 4$ goats. Combination with cattle and goats was $1 / 2$ cattle and $1 / 2$ goats.

\section{by using livestock combinations.}

Under continuous grazing at the heavy stocking rate, sacahuista poisoning occurred in goats in 11 of the 20 years of the study when goats were grazed alone, in 7 years when cattle and goats were grazed together, and in only 2 years with a combination of cattle, sheep, and goats. At the moderate rate it occurred in 5 years of 20 when goats were grazed alone, in only 3 with a combination of cattle, sheep, and goats, and in only 3 years with the combination of cattle and goats. The low frequency of poisoning in the heavily stocked cattle, sheep, and goat pasture was attributed to lesser amounts of sacahuista in this pasture than in the pastures stocked moderately with the combination of livestock. Poisoning occurred in 2 of the 20 years when goats were grazed alone and when cattle and goats were grazed together at a light stocking rate, but there were no death losses from sacahuista when cattle, sheep, and goats were grazed in combination at a light rate of stocking.

Significantly, no sacahuista poisoning occurred on the 4pasture deferred-rotation system where cattle, sheep, and goats were grazed in combination at the moderate rate. This is despite the fact that due to increased carrying capacity obtained with the 4-pasture deferred-rotation system the stocking rate was increased to 43 animals per section for the moderate rate of stocking during the last 10 years of the study. The moderate rate of stocking under continuous grazing remained at 32 animal units per section.

\section{Oak Poisoning}

Both liveoak and shinoak are considered fairly good forage for livestock during much of the year. Liveoak provides green forage for both livestock and deer during the winter months when little green forage is available. They do, however, cause poisoning during certain periods of the year. During this study, losses occurred only during the spring budding period and only goats were affected (Table 3 ). However, both cattle and sheep were also lost from oak

Table 3. Average yearly death losses $(\%)$ of goats from oak poisoning under continuous grazing at different rates of stocking and at three kinds or combinations or livestock on the Sonora Experiment Station, 1949-70.

\begin{tabular}{lcccc}
\hline \multirow{2}{*}{ Kind of livestock } & \multicolumn{4}{c}{ Stocking rate } \\
\cline { 2 - 5 } & Heavy & Moderate & Light & Avg. \\
\hline Goats only & 1.7 & 2.1 & 0.8 & 1.5 \\
Goats and cattle & 3.3 & 2.5 & 0.4 & 2.1 \\
Goats, cattle, and sheep & 4.4 & 3.3 & 0.0 & 2.6 \\
Avg. \% loss & 3.1 & 2.6 & 0.4 & \\
\hline
\end{tabular}

'Stocking rate: Heavy $=48 \mathrm{au} / \mathrm{sec} ;$ Moderate $=32 \mathrm{au} / \mathrm{sec} ;$ Light $=16 \mathrm{au} / \mathrm{sec}$.

${ }^{2}$ Combination in a nimal units with cattle, sheep, and goats was $1 / 2$ cattlc, $1 / 4$ shcep, and $1 / 4$ goats. Combination with cattle and goats was $1 / 2$ cattle and $1 / 2$ goats. poisoning on surrounding ranches during the period of the study.

Under continuous grazing the greatest average yearly losses in goats occurred in the pastures which were heavily stocked $(3.1 \%)$; second on pastures moderately stocked $(2.6 \%)$; and least on pastures lightly stocked $(0.4 \%)$.

Grazing a combination of animals compared to grazing goats alone did not prevent death losses under moderate and heavy continuous grazing since the greatest average yearly losses occurred when cattle, sheep, and goats were grazed together, and the lowest when goats were grazed alone (Table 3). No goats were lost from oak poisoning at light continuous grazing with cattle, sheep, and goats or at moderate stocking rates with cattle, sheep, and goats under a 4-pasture deferred-rotation system of grazing.

The range condition on all pastures was low-fair to poor at the start of the study. The range condition of all heavily grazed pastures remained in low-fair to poor condition throughout the study, but it was obvious that more of the preferred plants were available for each kind of livestock where combinations were used than where single kinds were grazed alone. This availability of forage was probably the reason that more goats were lost from oak poisoning when cattle, sheep and goats were grazed together than when goats were grazed alone. Apparently goats were able to be more selective when grazed alone, and thus could vary their diet enough to avoid poisoning when not competing for forage with other kinds of livestock.

\section{Discussion}

The moderately stocked continuously grazed pastures all made range improvement during the period of the study. The improvement was from low-fair or poor up to fair or high-fair. Vegetation surveys were not accurate enough to delineate range condition differences between pastures which are stocked at the same rate but with different combinations of animals. However, visual observations over the 20-year period confirm that forage differences were present on pastures grazed with a combination of animals compared with single kinds.

The lightly stocked continuously grazed and moderately stocked pastures grazed under the 4-pasture rotation system, improved in range condition from low-fair to poor to good or high-good, and on some range sites to excellent range condition. Although stocking density was $1 / 3$ greater on the three pastures of the 4-pasture system that were being grazed than on the moderately stocked continuously grazed pastures, no livestock poisoning was encountered. This might be explained by the fact that all pastures on the study were rested for 8 months before the start of the study. Rainfall was normal during this period and good vegetative growth occurred. No death losses occurred on any pasture the first two years, even on heavily stocked pastures. Two good rainfall years following the start of the study resulted in good range improvement at the ligh1 stocking rates and on the 4-pasture system with moderate stocking rates. This early start enabled enough vegetation improvement to provide a good diet for animals under ligh1 grazing and the 4-pasture system. Although the improving range condition under the 4-pasture system allowed the stocking rate to be increased from 32 to 43 animal units pes section during the last 10 years of the study, forage conditions throughout were adequate to prevent losses from poisonous plants. 
The complete lack of poisonous plant losses on the moderately stocked 4-pasture system and the lightly stocked continuously grazed pastures is significant. The value of good range condition in preventing losses from poisonous plants is undeniable whether it be accomplished with light grazing rates or with a deferred-rotation system of grazing. Since two to three times more animals can be grazed with the rotation grazing system than continuous light grazing, the deferred-rotation grazing system is the most practical and economical means of preventing livestock poisoning by poisonous plants.

\section{Literature Cited}

Cory, V. L. 1949. African rue (Peganum harmula) in the United States. Field \& Laboratory. 17:20-23.
Dollahite, J. W., G. T. Householder, and B. J. Camp. 1966. Oak poisoning in livestock. Texas Agr. Exp. Sta. Bull. 1049. 8 p.

Hardy, W. T., V. L. Cory, H. Schmidt, and W. H. Dameron. 1931. Bitterweed poisoning in sheep. Texas Agr. Exp. Sta. Bull. 433. 18 p.

James, L. F., and A. E. Johnson. 1976. Some major plant toxicities of the Western United States. J. Range Manage. 29:359-363.

James, L. F., K. L. Bennett, K. G. Parker, R. F. Keller, W. Binns, and B. J. Lindsey. 1968. Loco plant poisoning in sheep. J. Range Manage. $21: 360$.

Sperry, O. E. 1949. The control of bitterweed (Actinea odorata) on Texas ranges. J. Range Manage. 2:122-127.

Sperry, O. E., J. W. Dollahite, G. O. Hoffman, and B. J. Camp. 1963. Texas plants poisonous to livestock. Texas Agr. Exp. Sta. Bull. 1028. $59 \mathrm{p}$.

Stoddart, L. A., and A. D. Smith. 1943. Range Management, 1st ed. McGraw-Hill Book Co., New York. 514 p.

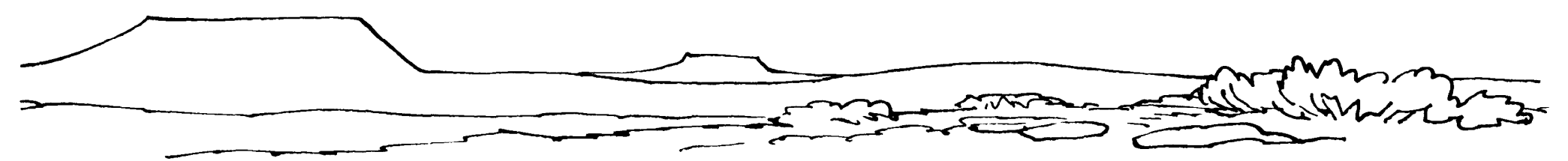

